\title{
Assessment of Microbial Quality of Chlorinated Drinking Tap Water and Susceptibility of Gram Negative Bacterial Isolates Towards Chlorine
}

\author{
Suraj Bishankha ${ }^{1}$, Tista Prasai Joshi ${ }^{2}$, Dev Raj Joshi ${ }^{1}$ and Dwij Raj Bhatta ${ }^{1}$ \\ ${ }^{1}$ Central Department of Microbiology \\ Tribhuvan University \\ Kirtipur, Kathmandu \\ ${ }^{2}$ Nepal Academy of Science and Technology \\ Khumaltar, Lalitpur \\ e-mail: suraj.apple@gmail.com
}

\begin{abstract}
Sixty (56.1\%) water samples crossed the permissible limit of WHO guideline value in heterotrophic plate count and total coliform count each. Ten different genera of gram negative bacteria were recovered in which $E$. coli was predominant followed by Citrobacter spp., Shigella spp., Enterobacter spp., Providencia spp., Klebsiella spp., Salmonella spp., Pseudomonas spp., Proteus spp. and Edwardsiella spp. Higher the temperature of water sample, higher the bacterial growth was obtained $(\mathrm{p}=0.002)$, and similarly higher level of free residual chlorine in water reduced the bacterial growth $(\mathrm{p}=0.037)$ whereas increase or decrease of $\mathrm{pH}(\mathrm{p}=0.454)$, turbidity $(\mathrm{p}=0.164)$ and conductivity $(\mathrm{p}=0.969)$ did not affect the microbial growth. A negative correlation $(\mathrm{r}=-0.162)$ between heterotrophic plate count and free residual chlorine was observed, however, without statistical significance $(p=0.096)$. Similarly, a negative correlation $(\mathrm{r}=-0.383)$ between total Coliform count and free residual chlorine was observed with statistical significance $(p=0.001)$. In chlorine assay, all tested eight genera of gram negative bacteria were found to be chlorine resistant at $0.2 \mathrm{mg} / \mathrm{l}$ for a contact time of 30 minutes. Average time required for $\mathrm{T}_{99.9}(3-\log )$ and $\mathrm{T}_{99.99}$ (4-log) reduction of viable isolates from initial population of $2 \times 10^{6}$ cells $/ \mathrm{ml}$ were found to be less than 30 minutes and greater than 60 minutes respectively. Log inactivation of various bacterial isolates with chlorine concentration of $0.2 \mathrm{mg} / \mathrm{l}$ for a contact time of 30 minutes were found to be ranged from 3 to $3.5-\log$. Emergence of chlorine resistant organisms in drinking water probably demands alternate disinfection or mitigation strategy.
\end{abstract}

Key words: chlorine resistance, disinfection, residual chlorine, heterotrophic plate count, total Coliform count

\section{Introduction}

Around 1.2 billion people around the world lack access to safe drinking water and twice that many lack adequate sanitation. As a result, the World Health Organization (WHO) estimated that 3.4 million people, mostly children, die every year from water-related diseases (WHO 2002). In Nepal, the total cases of diarrhoea were 1,398,106 and among them 206 diarrhoeal death occurred in the fiscal year (FY) (2007/ 2008). Among the top ten reasons for hospitalization, on the same FY, diarrhoeal and gastroenteritis of presumed infectious origin becomes the $2^{\text {nd }}$ leading causes and accounts $5.40 \%$ of total patients hospitalized (DoHS (2007/2008). Many of the water borne diseases can be prevented with appropriate water treatment and proper sanitation and hygiene practices.

Disinfection is an important final step among different steps in drinking water treatment and is the principle barrier for preventing pathogen breakthrough into water supply systems. Chlorination is the most widely used method of disinfection for community water distribution systems and reservoirs; however, there may be an increased resistance of bacterial strains to chlorine inactivation (Ridgway \& Oslon 1982, Howard \& Inglis, 2003 and Goel \& Bouwer 2004). Detection of 
Coliforms in high-quality treated waters is often attributed to ineffective disinfection and/or bacterial regrowth in distribution systems (LeChevallier 1990). The formation of sessile communities and their inherent resistances to disinfectants are potentially a significant cause of persistent and short term deterioration on microbiological water quality in drinking water distribution systems (Lee \& Kim 2003).

Bacteria from chlorinated systems were more resistant than those from the unchlorinated waters (Geldreich 1996). Free chlorine has been suggested to be the water quality parameter that reacts with the widest range of contaminants (USEPA 2003). Chlorination when properly designed and operated, the process is welldeveloped, inexpensive and efficient. However, several drawbacks of chlorine-based disinfection systems have been identified, including the formation of potentially hazardous disinfection by-products and the discovery of waterborne microbial pathogens that are relatively resistant to chlorine inactivation. These factors define the risks to be balanced in the design of disinfection systems, and dictate new optimization strategies for chlorination (Shang \& Blatchley 2001).

The efficiency of drinking water treatment against the gram negative bacterial isolates should be regularly monitored as water treatment plants could not eliminate all Coliforms (Lechevallier et al. 1996). If chlorine-resistant microbial forms exist, they should be recovered from chlorinated water distribution systems (Ridgway \& Olson 1982). Therefore, this study was carried out to assess the physicochemical and bacterial quality of drinking water and to explore the chlorine resistant gram negative bacteria in the municipal drinking water supplies of Kathmandu metropolitan city.

\section{Methodology}

This study was conducted at the Environment and Climate Change Study Laboratory of Nepal Academy of Science and Technology from April 2009 - August 2010. A total of 107 water samples were randomly collected from Bansbari (52) and Mahankalchaur (55) treatment and distribution plant. The water treatment and distribution plant uses the chlorination process with the free residual chlorine of 0.1-0.2 ppm for a contact time of 30 minutes (MPPW 2005).

\section{Physicochemical analyses of water samples}

Physicochemical parameters of water - $\mathrm{pH}$, turbidity, conductivity and temperature were measured using calibrated $\mathrm{pH}$ meter, Nephelometer, conductivity meter, and mercury thermometer respectively (APHA 1998). Field determination of free, combined and total residual chlorine was determined by chlorometer on spot. All testes were done within 4 hours of sample collection.

Microbiological sampling and taxonomic identification The samples were collected aseptically from randomly selected tap water in sterile bottles containing 3\% $(w / v)$ \& sodium thiosulfate solution. The water samples were transported maintaining cold chain with ice box and analysed at maximum within 4 hours of collection where appropriate portions $(100 \mathrm{ml})$ were filtered through $0.45 \mu \mathrm{m}$ membrane filters and placed in M-endo agar. Samples of $0.1 \mathrm{ml}$ were also spread plated on to plate count agar. The plates were incubated at $35^{\circ} \mathrm{C}$ for 2 days, colonies were enumerated and transferred to nutrient agar slants and stored at $4^{\circ} \mathrm{C}$ for subsequent taxonomic identification. Gram negative bacteria were identified according to the characteristics described in Bergey's manual (1994).

\section{Determination of Bacterial Chlorine Resistance}

\section{Liquid assay procedure}

Bacteria were grown overnight in tryptic soy broth in an orbital shaker at $23^{\circ} \mathrm{C}$. The cells were harvested by centrifugation at $3,500 \times \mathrm{g}$ for 15 minutes and were washed twice in sterile ice-cold 50mM monobasic potassium phosphate buffer ( $\mathrm{pH}$ 7.0). After the final centrifugation, the bacteria were suspended in buffer to an optical density of 1.05 (measured at $580 \mathrm{~nm}$ ), and $10 \mu \mathrm{l}$ of this suspension was transferred to each of 7 reaction tubes containing $10 \mathrm{ml}$ of the $50 \mathrm{mM}$ phosphate buffer. The final cell concentration in each tube was approximately $4.0 \times 10^{6}$ per ml. Equi-volume of sample and double strength calcium hypochlorite solution were mixed to obtain the desired half concentration of both samples and calcium hypochlorite solution in next six reaction tubes. The last one tube served as an untreated control and received no chlorine but instead equi-volume of sample and sterile chlorine demand free distilled water was added. The applied calcium hypochlorite concentrations in the tubes were varied from 0 to $1.25 \mathrm{mg} / \mathrm{l}$. After time $(\mathrm{t})=0,15,30,45$ and 60 minutes at $23^{\circ} \mathrm{C}, 100 \mu \mathrm{l}$ of sterile $1.0 \mathrm{M}$ sodium thiosulfate was added to each tube. The tubes were chilled to $2^{\circ} \mathrm{C}$, and portions were plated on Plate Count 
Agar to rescue surviving bacteria. The plates were incubated at $35^{\circ} \mathrm{C}$ for 48 hours, and colonies were enumerated (Ridgway \& Olson 1982).

\section{Results and Discussion}

\section{Physicochemical and microbiological analyses}

The conductivity of all water samples was found within the WHO guideline value but not all of the samples for $\mathrm{pH}$, turbidity and free residual chlorine were found within the WHO guideline value. The bacteriological analysis of water samples showed that 60 (56.1\%) samples were above the WHO guideline value for total coliform and heterotrophic plate count each. A total of 134 bacteria of 10 different genera were isolated and identified, where $E$. coli was predominant followed by Citrobacter spp., Shigella spp., Enterobacter spp., Providencia spp., Klebsiella spp., Salmonella spp., Pseudomonas spp., Proteus spp. and Edwardsiella spp. There was a significant relation between temperature $(p=0.002)$, free residual chlorine $(p=0.037)$ and growth of the organisms but no significant relation between the conductivity $(\mathrm{p}=0.969), \mathrm{pH}(\mathrm{p}=0.454)$ and turbidity $(\mathrm{p}=0.164)$ (Table 1). The correlation between heterotrophic plate count and free residual chlorine was found insignificant ( $\mathrm{p}=$ $0.096)$ with negative correlation $(\mathrm{r}=-0.162)$. Likewise, the correlation between total coliform count and free residual chlorine was found significant $(\mathrm{p}=0.001)$ with negative correlation ( $\mathrm{r}=-0.383$ ) (Fig 1 and 2).

Table 1. Difference of conductivity, pH, temperature and turbidity between the growth of organisms

\begin{tabular}{l|l|l|l}
\hline Variables & Growth $(\mathrm{N}=71)$ & No growth $(\mathrm{N}=36)$ & $\mathrm{p}$-value \\
\hline Conductivity & $58.28 \pm 24.499$ & $58.47 \pm 24.754$ & 0.969 \\
p H & $7.199 \pm 0.413$ & $7.264 \pm 0.444$ & 0.454 \\
Temperature & $16.596 \pm 3.962$ & $14.328 \pm 1.885$ & 0.002 \\
Turbidity & $1.797 \pm 4.870$ & $0.656 \pm 0.350$ & 0.164 \\
\hline
\end{tabular}

\section{Bacterial chlorine resistance}

Bacterial isolates of eight different genera, namely Escherichia coli, Enterobacter spp., Citrobacter spp., Klebsiella spp., Shigella spp., Salmonella spp., Providencia spp. and Pseudomonas spp. were tested and found to be chlorine resistant at concentration of $0.2 \mathrm{mg} / \mathrm{lt}$ for a contact time of 30 minutes. Time required for reducing the organisms by 3-log $\left(\mathrm{T}_{99.9}\right)$ and 4-log $\left(\mathrm{T}_{99.99}\right)$ at Nepal standard of $0.2 \mathrm{mg} / \mathrm{l}$ of residual chlorine concentration were found to be less than 30 minutes and greater than 60 minutes for all eight different types

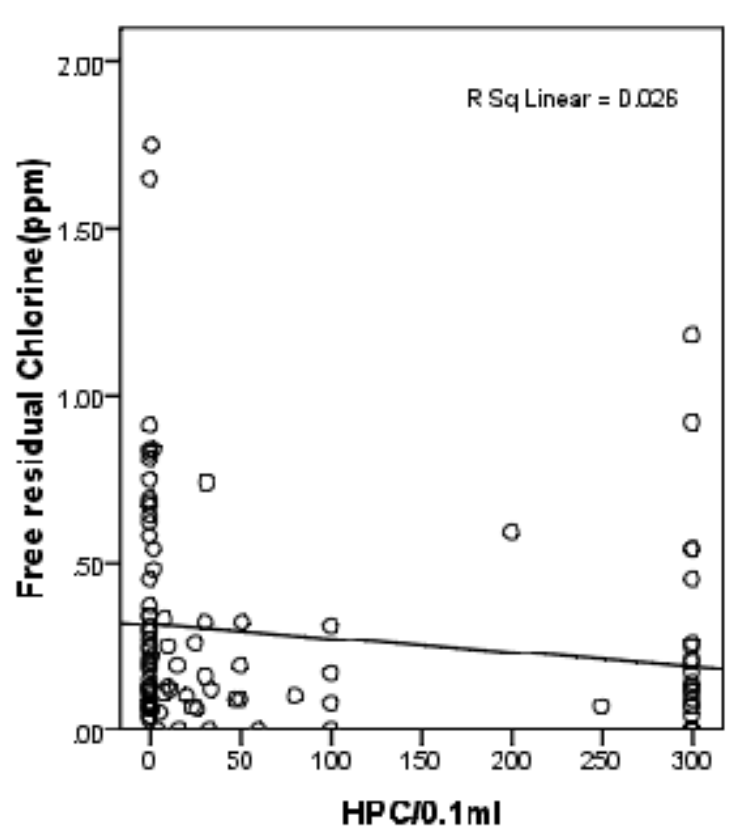

Fig. 1. Relation between free residual chlorine and heterotrophic plate count

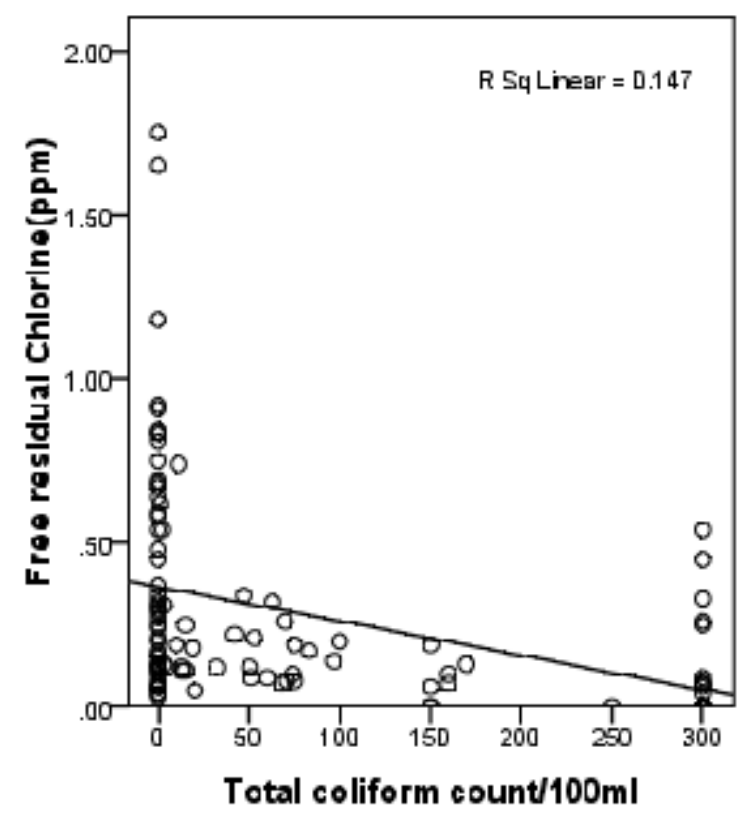

Fig. 2. Relation between free residual chlorine and total Coliform counts

of organisms tested. Log inactivation of various organisms with the residual concentration at Nepal standard was found to be the highest reduction of Citrobacter spp. (3.54-log) to the lowest of Escherichia coli (3.097-log) (Table 2). 
Table 2. Log inactivation of various organisms with chlorine concentration of $0.2 \mathrm{mg} / \mathrm{l}$ for a contact time of 30 minutes

\begin{tabular}{lc}
\hline Organisms & Log inactivation \\
\hline Citrobacter spp. & 3.545 \\
Klebsiella spp. & 3.426 \\
Shigella spp. & 3.260 \\
Providencia spp. & 3.240 \\
Pseudomonas spp. & 3.240 \\
Enterobacter spp. & 3.190 \\
Salmonella spp. & 3.125 \\
Escherichia coli & 3.097 \\
\hline
\end{tabular}

Microbial quality of drinking water was assessed by physicochemical and microbial parameters. The temperature of the analyzed water varied between 10.2 to $26.3^{\circ} \mathrm{C}$ with the average temperature $15.8^{\circ} \mathrm{C}$. High temperature has negative impact on water quality by enhancing microbial growth, which may increase taste, odor, color and corrosion problem (UNICEF 2008). However, previously average temperature of drinking water of Kathmandu was slightly higher ranging from 18.7 - $19.2^{\circ} \mathrm{C}$ (Shrestha 2009 and Aryal 2009). All water samples for conductivity were found to be within WHO guideline value (d” $1500 \mu \mathrm{S} / \mathrm{cm}$ ). In agreement to this study, Gopali (2008) also reported all 111 water samples having conductivity within WHO guideline value. As for drinking water, it should remain constant; a sudden increase of conductivity indicates pollution. $\mathrm{pH}$ of $3.7 \%$ was found to be below the WHO guideline values (6.58.5). Jayana (2007) reported in agreement with this study that $6.66 \%$ samples were below WHO guideline value. Previously, Ridgway and Olson (1982), K.C. (1992), Prasai et al. (2007), Bajracharya et al. (2007) and Gopali (2008) found that all tested water samples were within WHO guideline value. $\mathrm{pH}$ of water gets changed with time due to exposure to air, biological activity and temperature changes (UNICEF 2008). Turbidity of 93.3\% water samples was within WHO guideline value (d” 5 NTU). Similarly, Bajracharya et al. (2007) revealed the turbidity which varied upto 48 NTU. Turbidity may result from insufficient filtration during water treatment of sediments, mineral precipitates or biomass within the distribution system (UNICEF 2008). The water samples collected were of high quality according to the current standards of Nepal except few samples which crossed the permissible limits.
The microbiological analyses of water revealed that $56.1 \%$ samples were above the WHO guideline value for the heterotrophic plate and total coliform count each. There was a decreasing trend of microbial contamination from 2007 to 2009 (Prasai et al. 2007, Gopali 2008 and Shrestha 2009). Coliform have been used extensively as the basis for regulating the microbial quality of drinking water. Good quality drinking water can suffer serious contamination in distribution systems because of breaches in the integrity of pipelines and storage reservoirs.

Physico-chemical parameters influence the growth of microorganism in water (Lechevallier et al. 1981). Increase in temperature increases the bacterial growth $(\mathrm{p}=0.002)$ whereas increase or decrease of $\mathrm{pH}(\mathrm{p}=$ $0.454)$, turbidity ( $p=0.164)$ and conductivity $(\mathrm{p}=0.969)$ did not affect the microbial growth. The association between the growth of organisms and the FRC (Free residual chlorine) was found to be significant $(\mathrm{p}=$ 0.037 ) means microbial load decreases with the increase in FRC. The correlation between the FRC and HPC was found to be negatively correlated $(r=$ $0.162)$ and insignificant $(p=0.092)$ means FRC and HPC did not affect each other. But the correlation between the FRC and total coliform count (TCC) was found to be negatively correlated $(r=-0.383)$ and significant ( $p=0.001)$ means FRC and TCC affect each other. Similarly, Gopali (2008) reported that the correlation between FRC and HPC was negatively correlated and was found to be insignificant at $(\mathrm{p}<0.05)$ in Balaju reservoir but was found significant in Sundarighat reservoir. But the correlation between FRC and TCC was found to be negatively correlated and was significant in Sundarighat reservoir but was found insignificant in Balaju reservoir.

Eight genera of bacterial water isolates tested by chlorine assay method were found to be chlorine resistant at concentration of $0.2 \mathrm{mg} / \mathrm{l}$ of residual chlorine for a contact time of 30 minutes, (Nepal Standard). Sarbatly and Krishnaiah (2007) and Gopali (2008) found that total coliform were present in those samples which were within guideline value for free residual chlorine. Lechevallier et al. (1988) showed that the attachment of bacteria to surfaces provided the greatest increase in disinfection resistance. Other mechanisms which increased disinfection resistance included the age of the biofilm, bacterial encapsulation and previous growth condition which increased resistance to chlorine from 2 to 10 -fold. 
These resistance mechanisms were multiplicative.

Survival of the opportunistic pathogenic microorganisms and its persistence in the water distribution systems may be due to their capability to resist chlorine. The probable mechanism include: modification of cell surface structures which may lead to increase aggregation or clumping of cells in situ, microbial adhesion to pipe surfaces or to suspended particulate matter such as detritus or clay particles, extrusion of protective extracellular capsular or slime layers and formation of resistant spores.

The fact that relatively high numbers of microorganism could be routinely isolated from the chlorinated distribution plants suggests that certain bacteria may possess mechanisms enabling them to survive in chlorinated environments. Additional studies should be conducted to determine which mechanism leads bacteria to be resistant to chlorine as our study showed all the eight different genera of bacterial isolates tested were resistant.

Gram negative bacterial isolates were found to be chlorine resistant at $0.2 \mathrm{mg} / \mathrm{lt}$ for a contact of 30 minutes tested. Present Nepal guideline $0.2 \mathrm{mg} / \mathrm{lt}$ did not seem to be sufficient to disinfect at a contact time of 30 minutes. However, overall quality of drinking water and effective chlorination can be generalized by investigating other concerned parameters.

\section{Acknowledgements}

The authors are grateful to Nepal Academy of Science and Technology for providing the laboratory facility. Thanks are due to Mr. Gyanendra Bahadur Karki, Chief of Water Quality Section, Kathmandu Upatyaka Khanepani Limited (KUKL) for lending chlorometer.

\section{References}

APHA. 1998. Standard methods for the examination of water and wastewater. $20^{\text {th }}$ edition. American Public Health Association, Washington, DC.

Aryal, S.N. 2009. Isolation and Characterization of Escherichia Coli from Drinking Water of Urban Kathmandu. M. Sc. Dissertation. Central Department of Microbiology, Tribhuvan University, Kirtipur, Kathmandu, Nepal.

Bajracharya, A.M., K.D. Yami, T. Prasai, S.R. Basnyat and B. Lekhak. 2007. Assessment of drinking water quality of Kathmandu metropolitan areas. Nepal Journal of Science and Technology 8:113-118.
Codony, F; J. Morato and J. Mas, 2005. Role of discontinuous chlorination on microbial production by drinking water biofilms. Water Research, 39: 18961906.

Diwakar, J., K.D. Yami and T. Prasai. 2008. Assessment of drinking water of Bhaktapur municipality area in premonsoon season. Scientific World 6: 94-98.

DoHS. 2007/2008. Annual report. Ministry of Health and Population, Department of Health Services, Kathmandu, Nepal.

Geldreich, E E.1996. Microbial quality of water supply in distribution systems. CRC Press, Boca Raton, Florida USA.

Goel, S. and E.J.Bouwer.2004. Factors influencing inactivation of Klebsiella pneumonia by chlorine and chloramines. Water Research. 38: 301-308.

Gopali, J. 2008. Study of microbial quality of chlorinated drinking water of Kathmandu. M. Sc. Dissertation. Department of Microbiology, National College, Nayabazar, Kathmandu.

Holt, J.G, Krieg, N.R. P. H. A. Sneath, J.T. Staley, T. Stanley W. 1994. Bergey's manual of determinative bacteriology. Ninth Edition, International edition.

Howard, K. and T.J.J Inglis. 2003. The effect of free chlorine on Burkholderia pseudomallei in potable water. Water Research 37:4425-4432.

Jayana, B.L, T. Prasai, A. Singh and K.D. Yami. 2009. Assessment of drinking water quality of MadhypurThimi and study of antibiotic sensitivity against bacterial isolates. Nepal Journal of Science and Technology 10: 167-172.

K C. G. 1992. Studies on drinking water quality of Shivapuri main source to its Panipokhari reservoir and treatment plant and its distribution systems of Kathmandu valley. M. Sc. Dissertation. Central Department of Zoology, Tribhuvan University, Kirtipur, Kathmandu.

Lechevallier, M.W, T.M. Evans and R.J. Seidler. 1981. Effect of turbidity on chlorination efficiency and bacterial persistence in drinking water. Applied and Environmental Microbiology 42(1): 159-167.

Lechevallier, M.W, C.D. Cawthon and R.G. Lee.1988. Factors promoting survival of bacteria in chlorinated water supplies. Applied and Environmental Microbiology 54(3): 649-654.

Lechevallier, M.W. 1990. Coliform regrowth in drinking water: A review. Journal of American Water Works Association 82:74-86.

Lechevallier, M.W, N.J. Welch and D.B.Smith 1996. Fullscale studies of factors related to coliform regrowth in drinking water. Applied and Environmental Microbiology 62:2201-2211.

Lee, D.G. and S.J. Kim. 2003. Bacterial species in biofilm cultivated from the end of the Seoul water distribution system. Journal of Applied Microbiology 95, 317-324. 
Nepal Journal of Science and Technology Vol. 13, No. 1 (2012) 173-178

Ministry of Physical Planning and Works. 2005. National drinking water quality standards, implementation directives for National Drinking Water Quality Standards, MPPW, Kathmandu

Prasai, T., D.R. Joshi, B. Lekhak and M.P. Baral 2007. Microbiological analysis of drinking water of Kathmandu valley. Scientific World 5:112-114.

Ridgway, H.F. and B.H. Olson. 1982. Chlorine resistance patterns of bacteria from two drinking water distribution systems. Applied and Environmental Microbiology 44(4): 972-987.

Sarbatly, R.H.J and D. Krishnaiah. 2007. Free chlorine residual content within the drinking water distribution system. International Journal of Physical Sciences 2(8): 196-201.

Shang, C. and Blatchley, III ER. 2001. Chlorination of pure bacterial cultures in aqueous solution. Water Research 35(1): 244-254.

Shrestha, E. 2009. Isolate and identify Salmonella from drinking water samples of UWSS of Kathmandu district and determine the antibiotic susceptibility pattern of isolates. M. Sc. Dissertation. Central Department of Microbiology, Tribhuvan University, Kirtipur, Kathmandu.

United Nations Children's Fund (UNICEF). 2008. UNICEF handbook on water quality, UN Plaza, New York, NY 10017.

USEPA.2003. National primary drinking water regulations. http:// www.epa.gov.

World-Health-Organization.2002. Water and sanitation: facts and figures. http://www.who.int/ water_sanitation_health/General/factsandfigures.htm. 